\title{
Pengaruh Lama Penyimpanan Ampas Kelapa yang Diberi Ekstrak Daun Kersen (Muntingiaca labura L.) dalam Kemasan Karung Blacu terhadap Kualitas Fisik Organoleptik
}

\author{
Effect of Storage Duration of Coconut Waste Added with Cherry Leaf Extract in Cloth Sacks \\ on Organoleptic Physical Quality
}

\author{
R. A. Pertiwi, R. I. Pujaningsih dan S. Mukodiningsih \\ Fakultas Peternakan dan Pertanian, Universitas Diponegoro \\ Corresponding Author: renni_anie@yahoo.com
}

\begin{abstract}
This study aims to examine the problem of storage time for the organoleptic physical quality of coconut waste added cherry leaf extract. Cherry leaf extract was extracted using the socletation method. Concentration of cherry leaf extract is $50 \%$. Coconut waste treated with A0 (without cherry of leaf extract), A1 (with cherry leaf extract) giving cherry leaf extract with a ratio of $1: 10(\mathrm{v} / \mathrm{w})$ and given a different treatment of storage time from each other, T0 (storage time 0 week), T1 (2nd week storage time) and T2 (4th week storage time). The experiment method used was a Completely Randomized Design (CRD) with factorial $2 \times 3$ with 5 replications. The parameters used were organoleptic test consisting of texture, color, flavour and presence of fungi. The results showed that the duration of storage and adding of leaf extracts in coconut waste were not significant $(\mathrm{P}>$ 0.05) on organoleptic consisting of texture, color, flavour and presence or absence of fungi. Cherry leaf extract that added to coconut waste can reduce the organoleptic quality which includes texture, color, flavour and presence of fungi during storage.
\end{abstract}

Keywords: Coconut waste, cherry leaf extract, organoleptic test, storage time.

\begin{abstract}
ABSTRAK
Penelitian ini bertujuan untuk untuk mengkaji pengaruh lama penyimpanan tarhadap kualitas fisik organoleptik ampas kelapa yang diberi ekstrak daun kersen. Ekstrak daun kersen diekstraksi menggunakan metode sokletasi. Konsentrasi ekstrak daun kersen yang digunakan adalah 50\%. Ampas kelapa diberi perlakuan yaitu A0 (tanpa pemberian ekstrak daun kersen), A1 (dengan pemberian ekstrak daun kersen) pemberian ekstrak daun kersen dengan perbandingan $1: 10(\mathrm{v} / \mathrm{w})$ dan diberi perlakuan lama penyimpanan yang berbeda, masing-masing T0 (lama penyimpanan minggu ke -0), T1 (lama penyimpanan minggu ke-2) dan T2 (lama penyimpanan minggu ke - 4). Rancangan yang digunakan adalah rancangan acak lengkap (RAL) pola faktorial $2 \times 3$ dengan 5 ulangan. Parameter yang diamati yaitu uji organoleptik yang terdiri dari tekstur, warna, aroma dan ada tidaknya jamur. Hasil penelitian menunjukkan bahwa lama penyimpanan dan pemberian ekstrak daun kersen pada ampas kelapa berpengaruh nyata $(\mathrm{p}<0,05)$ terhadap uji organoleptik yang terdiri dari tekstur, warna, aroma dan ada tidaknya jamur. Ekstrak daun kersen yang ditambahkan pada ampas kelapa mampu menekan terjadinya penurunan kualitas organoleptik yang meliputi tekstur, warna, aroma dan ada tidaknya jamur selama penyimpanan.
\end{abstract}

Kata kunci: Ampas kelapa, ekstrak daun kersen, uji organoleptik, lama penyimpanan.

\section{PENDAHULUAN}

Pemanfaatan limbah pertanian sebagai pakan ternak merupakan salah satu cara pemecahan masalah biaya produksi yang tinggi pada industri peternakan. Kelayakan limbah pertanian dijadikan pakan didukung dengan kandungan nilai nutrisinya. Salah satu limbah pertanian yang tersedia dalam jumlah yang banyak dan belum dimanfaatkan secara optimal sebagai bahan baku pakan ialah ampas kelapa.
Ampas kelapa yang merupakan hasil samping pembuatan santan yang masih memiliki kandungan nutrisi yang cukup tinggi. Produksi kelapa di Indonesia pada tahun 2011 yang mencapai 3,1 juta ton, sedangkan penggunaan kelapa untuk pembuatan santan di Indonesia mencapai 600 juta butir per tahun (Cahya dan Susanto, 2014). Hal ini menyebabkan ampas kelapa 
berpotensi untuk dimanfaatkan dan diolah menjadi bahan pakan. Berdasarkan hasil analisis ampas kelapa memiliki kandungan nutrisi protein kasar sebesar 5,78\%, lemak kasar 38,24\% dan serat kasar 15,07\% (Putri, 2010).

Kandungan lemak yang tinggi pada ampas kelapa dapat menyebabkan ampas kelapa mudah tengik dan mutunya menjadi jelek selama penyimpanan. Rendahnya daya simpan ampas kelapa dapat disebabkan oleh kandungan lemak yang tinggi serta pengaruh lingkungan serta oksigen dan kontaminsai mikroorganisme. Agar ampas kelapa ini dapat bermanfaat dan mampu bertahan lama maka dapat dilakukan proses pengolahan dan penyimpanan.

Selain proses pengolahan dan penyimpanan pada bahan pakan, diperlukan proses pengawetan yang digunakan untuk mempertahankan mutu bahan pakan. Proses pengawetan dilakukan secara kimia yaitu dengan pemberian daun kersen (Muntingia calabura L.) yang berfungsi sebagai antibakteri, antioksidan dan antimikroba. Daun kersen mengandung flavonoid, tanin dan saponin (Dwi, 2014). Kandungan tersebut yang membuat daun kersen (Muntingia calabura L.) memiliki potensi antioksidan dan aktivitas antibakteri.

Flavonoid pada beberapa tumbuhan diketahui memiliki sifat antibakteri (Mirzoeva et al., 1997). Flavonoid mampu melepaskan energi transduksi terhadap membran sitoplasma bakteri dan menghambat motilitas bakteri. Senyawa tannin pada daun kersen dapat menghambat aktifitas enzim protease, selain itu tannin juga mampu mengkerutkan dinding sel bakteri sehingga dapat menganggu permeabilitas sel, sehingga sel bakteri tersebut tidak dapat melakukan aktivitas hidup sehingga pertumbuhannya terhambat atau bahkan mati (Mahardika et al., 2014). Saponin dalam daun kersen akan menganggu tegangan permukaan dinding sel, sehingga zat antibakteri akan masuk dengan mudah ke dalam sel sehingga metabolisme terganggu dan bakteri akan mati (Karlina et al., 2013).
Tujuan dari penyimpanan adalah untuk menjaga dan mempertahankan mutu komoditi yang disimpan dengan cara menghindari, mengurangi ataupun menghilangkan berbagai faktor yang dapat menurunkan kualitas dan kuantitas komoditi tersebut (Izzah, 2011). Proses penyimpanan biasa dilakukan dengan cara menyimpan bahan pakan di dalam gudang, namun proses penyimpanan akan mempengaruhi mutu pakan yang dihasilkan apabila penyimpanan dilakukan terlalu lama dan dalam kondisi yang tidak baik maka justru akan menurunkan mutu bahan pakan. Lama penyimpanan yang tidak sesuai dan cara menyimpan yang salah akan mengakibatkan pakan menjadi keras dan berjamur.

Kerusakan bahan pakan yang disebabkan oleh lingkungan selama penyimpanan dapat diatasi dengan cara mengemas produk pakan dengan kemasan yang baik. Kemasan yang biasa digunakan untuk mengemas bahan pakan yaitu karung, plastik dan kemasan kertas (Wigati, 2009). Jenis kemasan yang digunakan adalah karung blacu. Karung blacu yang terbuat dari bahan kapas sebagai bahan dasarnya ini memiliki sifat yang fleksibel, ramah lingkungan dan dapat dengan mudah ditemukan di masyarakat.

Kualitas pakan yang disimpan akan turun apabila disimpan melebihi batas waktu tertentu, oleh sebab itu uji fisik organoleptik penting untuk diketahui. Uji fisik organoleptik pakan merupakan uji dasar pada pakan, sehingga dengan mengetahui uji fisik organoleptik dari pakan dapat mengetahui batas maksimal penyimpanan pakan. Uji fisik organoleptik meliputi : tekstur, aroma, warna dan ada tidaknya jamur. Penelitian ini bertujuan untuk mengkaji pengaruh lama penyimpanan tarhadap kualitas fisik organoleptik ampas kelapa yang diberi ekstrak daun kersen. Manfaat yang dapat diperoleh dari penelitian ini adalah memperoleh informasi tentang pengaruh lama penyimpanan terhadap kualitas fisik organoleptik ampas kelapa yang diberi ekstrak daun kersen. 


\section{MATERI DAN METODE}

Penelitian dilaksanakan selama 8 bulan di Laboratorium Teknologi Pakan, Fakultas Peternakan dan Pertanian, Universitas Diponegoro, Semarang. Analisis Proksimat di Laboratorium Ilmu Nutrisi dan Pakan, Fakultas Peternakan dan Pertanian, Universitas Diponegoro, Semarang. Analisis Flavonoid di Laboratorium Teknik Kimia, Fakultas Teknik, Universitas Negeri Semarang, Semarang.

Materi yang digunakan pada penelitian ini adalah daun kersen yang berwarna hijau tua, ampas kelapa dan etanol 97\%. Alat yang digunakan adalah alat tulis, baskom untuk tempat daun kersen, plastik cor untuk alas menjemur daun kersen, loyang kecil untuk tempat untuk mengoven daun kersen, stopless untuk tempat serbuk daun kersen, karung blacu sebagai wadah untuk menyimpan ampas kelapa, alat jahit untuk menjahit karung blacu, oven untuk mengoven daun kersen, blender untuk menghaluskan daun kersen, ayakan untuk mengayak daun kersen setelah diblender dan timbangan analitik yang digunakan untuk menimbang serbuk daun kersen dan ampas kelapa. Nampan digunakan untuk tempat mengoven daun. Alumunium foil yang digunakan untuk melapisi nampan saat mengoven daun, gelas ukur, botol sampel untuk menyimpan ekstrak daun kersen yang sudah di ekstraksi dan aquadest. Metode yang digunakan dalam penelitian ini meliputi rancangan penelitian, prosedur penelitian dan analisis data.

\section{Rancangan Penelitian}

Penelitian ini menggunakan RAL pola faktorial $2 \times 3$ dengan 5 kali ulangan. Faktor A adalah faktor penambahan ekstrak. A0 adalah (ampas kelapa tidak diberi ekstrak), A1 adalah (ampas kelapa diberi ekstrak 50\%). Faktor $\mathrm{T}$ adalah perbedaan lama penyimpanan yaitu: T0 (penyimpanan 0 minggu), T1(penyimpanan 2 minggu) dan T2 (penyimpanan 4 minggu). Kombinasi perlakuan tersebut yaitu sebagai berikut :
A0T0 : Ampas kelapa tidak ditambah ekstrak daun kersen penyimpanan 0 minggu, kemasan karung blacu

A0T1 : Ampas kelapa tidak ditambah ekstrak daun kersen penyimpanan 2 minggu, kemasan karung blacu

A0T2 : Ampas kelapa tidak ditambah ekstrak daun kersen penyimpanan 4 minggu, kemasan karung blacu

A1T0 : Ampas kelapa ditambah ekstrak daun kersen $50 \%$ penyimpanan 0 minggu, kemasan karung blacu

A1T1 : Ampas kelapa ditambah ekstrak daun kersen $50 \%$ penyimpanan 2 minggu, kemasan karung blacu

A1T2 : Ampas kelapa ditambah ekstrak daun kersen $50 \%$ penyimpanan 4 minggu, kemasan karung blacu

Prosedur penelitian ini meliputi tahap persiapan, tahap perlakuan, tahap pengumpulan data dan tahap analisis data.

\section{Tahap Persiapan}

Tahap Penelitian dilakukan dengan tiga tahapan meliputi penelitian pendahuluan, penelitian lanjutan dan tahap analisis. Penelitian pendahuluan meliputi persiapan alat dan bahan yang digunakan dalam penelitian yaitu pembuatan ekstrak daun kersen menggunakan metode sokletasi dan penyediaan ampas kelapa.

Tahapan pembuatan ekstrak daun kersen diawali dengan mengumpulkan daun kersen yang dibutuhkan dan mencuci daun kersen tersebut. Daun yang telah dicuci diangin-anginkan selama semalam, kemudian daun dimasukkan ke dalam oven dengan suhu $60^{\circ} \mathrm{C}$ selama 24 jam (Mahardika et al., 2014). Daun yang telah dioven memiliki kadar air sebesar $12 \%$, kemudian dihaluskan menggunakan blender dan diperoleh serbuk daun kersen. Selanjutnya dibuat ekstrak daun kersen dengan perbandingan serbuk dan air 1 : 1 , setelah itu dilakukan pemisahan dengan metode sokletasi pada suhu $70^{\circ} \mathrm{C}$ sampai tetesan tidak berwarna lagi. Selanjutnya dilakukan analisis kuantitatif dan kualitatif ekstrak daun kersen untuk mengetahui nilai flavonoid. 
Tahap selanjutnya adalah tahap penyediaan ampas kelapa. Ampas kelapa yang diperoleh dari pasar ditimbang beratnya kemudian dicuci. Setelah itu ampas kelapa dikeringkan matahari sampai kira-kira ampas kelapa tidak terlalu basah untuk disimpan. Kemudian dilakukan analisis proksimat di Laboratorium Nutrisi dan Pakan, Fakultas Peternakan dan Pertanian, Universitas Diponegoro, Semarang.

\section{Tahap Perlakuan}

Tahap selanjutnya adalah tahap perlakuan. Ampas kelapa diberi perlakuan yang berbeda yaitu dengan ditambahkan ekstrak daun kersen dan tidak ditambahkan ekstrak. Ekstrak daun kersen yang didapatkan diencerkan terlebih dahulu dengan perbandingan 1:1 yaitu ekstrak daun kersen : etanol 97\%. Dilanjutkan dengan pencampuran ampas kelapa dan hasil ekstraksi daun kersen dengan pencampuran ekstrak sebanyak $100 \mathrm{ml}$ per $1000 \mathrm{~g}$ ampas kelapa (perbandingan 1 : 10). Setelah pencampuran ampas kelapa dengan ekstrak, ampas kelapa ditempatkan pada karung blacu dengan berat masing - masing 250 gram. Pada tahap ini pengamatan sampel dilakukan pada minggu ke-0, minggu ke-2 dan minggu ke-4 selama penyimpanan. Uji mutu organoleptik dinilai oleh 15 panelis semi terlatih dan dilakukan pada saat ampas kelapa sebelum diberi perlakuan, selama perlakuan dan sesudah perlakuan dengan mengamati tekstur, warna, aroma dan ada tidaknya jamur. Tabel penilaian mutu organoleptik ampas kelapa terdapat pada (Tabel 1.)

Tabel 1. Penilaian mutu organoleptik ampas kelapa

\begin{tabular}{lcc}
\hline \multicolumn{1}{c}{ Kriteria } & \multicolumn{2}{c}{ Skor } \\
\cline { 2 - 3 } & Nilai & Angka \\
\hline Penampilan Tekstur Ampas Kelapa & & 4 \\
- Tekstur halus/lembut, tidak kasar, berair & Sangat Baik & 3 \\
- Tekstur agak kasar, sedikit berair. & Baik & 2 \\
- Tekstur kasar, kering tidak berair, remah. & Jelek & 1 \\
- Tekstur sangat kasar, sangat remah & Sangat Jelek & \\
\hline Penampilan Warna Ampas Kelapa & & 4 \\
- Putih Merata & Sangat Baik & 3 \\
- Putih kekuningan & Baik & 2 \\
- Kuning kecoklatan & Jelek & 1 \\
- Coklat kehitaman & Sangat Jelek & 4 \\
\hline Penampilan Aroma Ampas Kelapa & & 3 \\
- Khas Ampas Kelapa & Sangat Baik & 2 \\
- Agak tengik & Baik & 1 \\
- Tengik & Jelek & \\
- Sangat Tengik & Sangat Jelek & 4 \\
\hline Penampilan Ada tidaknya Jamur & & 3 \\
- Tidak terdapat jamur sama sekali & Sangat Baik & 2 \\
- Terdapat jamur tapi sangat sedikit & Baik & 1 \\
- Terdapat jamur agak banyak & Jelek & Sangat Jelek \\
- Terdapat jamur sangat banyak & & \\
\hline
\end{tabular}




\section{Tahap Pengumpulan Data}

Tahap berikutnya adalah tahap pengumpulan data yaitu mutu organoleptik pada ampas kelapa setelah penyimpanan dengan lama yang berbeda. Mutu organoleptik berupa tekstur, warna, aroma dan jamur.

\section{Uji Organoleptik}

Uji mutu organoleptik dilakukan dengan menyiapkan sampel seberat 50 gr yang telah diletakan di plastik untuk setiap perlakuan. Sampel tersebut kemudian akan dinilai tekstur, warna, aroma dan ada tidaknya jamur oleh 15 panelis semi terlatih menggunakan kuesioner.

\section{Tahap Analisis Data}

Tahap berikutnya adalah analisis data. Data dianalisis menggunakan analisis varians
(Anova) taraf signifikasi 5\% untuk mengetahui adanya pengaruh pada perlakuan terhadap kualitas fisik organoleptik. Apabila terdapat pengaruh maka dilakukan uji lanjut yaitu uji wilayah ganda Duncan untuk mengetahui perbedaan antar perlakuan.

$$
\gamma \mathrm{ijk}: \mu+\alpha \mathrm{i}+\beta \mathrm{j}+(\alpha \beta) \mathrm{ij}+\varepsilon \mathrm{ijk} ; \mathrm{i}=(1,2) \mathrm{j}=
$$$$
(1,2,3,4) \mathrm{k}=(1,2,3)
$$

\section{HASIL DAN PEMBAHASAN}

\section{Tekstur Ampas Kelapa}

Berdasarkan hasil penelitian pada (Tabel 2.) menunjukkan bahwa interaksi antara perlakuan penambahan ekstrak daun kersen (A) dan lama penyimpanan ( $\mathrm{T}$ ) berpengaruh nyata $(\mathrm{P}<0,05)$ terhadap tekstur ampas kelapa.

Tabel 2. Rata-rata skor nilai tekstur pada ampas kelapa

\begin{tabular}{ccccc}
\hline \multirow{2}{*}{ Pemberian } & \multicolumn{3}{c}{ Lama Penyimpanan } & \multirow{2}{*}{ Rata-rata } \\
\cline { 2 - 4 } Ekstrak & Minggu 0 & Minggu 2 & Minggu 4 & \\
\hline Tanpa Ekstrak (A0) & $3,23^{\mathrm{a}}$ & T1 & T2 & $2,84^{\mathrm{bc}}$ \\
Dengan Ekstrak (A1) & $3,36^{\mathrm{a}}$ & $2,94^{\mathrm{b}}$ & $2,36^{\mathrm{bc}}$ & $2,79^{\mathrm{d}}$ \\
\hline Rata-rata & 3,29 & 2,89 & 2,57 & 3,03 \\
\hline
\end{tabular}

Superskrip yang berbeda pada baris dan kolom yang sama menunjukkan perbedaan yang sangat nyata $(\mathrm{p}<0,05)$

Nilai rata-rata organoleptik terhadap tekstur berkisar antara 2,36 - 3,36. Nilai tertinggi diperoleh pada perlakuan A1T0, ini terjadi karena tekstur yang dihasilkan pada perlakuan A1T0 masih lembut dan tidak kasar. Perlakuan A0T2 memiliki skor terendah karena tekstur ampas kelapa menjadi sangat kasar dan remah. Selama proses penyimpanan tekstur ampas kelapa menjadi kasar dan remah. Hal ini kemungkinan terjadi karena adanya penurunan kadar air dari 14,56 menjadi $11,81 \%$, sehingga proses penyimpanan pada ampas kelapa mempengaruhi tekstur ampas kelapa. Hal ini sesuai dengan pendapat Miftahudin et al. (2015) yang menyatakan bahwa selama penyimpanan pakan akan terjadi proses evaporasi dari pakan ke lingkungan sekitar sehingga mengakibatkan penurunan nilai kadar air. Menurut pendapat
Retnani et al. (2009) kadar air pada permukaan bahan dipengaruhi oleh kelembaban nisbi (RH) udara sekitarnya, bila kadar air bahan rendah atau suhu bahan tinggi sedangkan RH disekitarnya tinggi maka terjadi penyerapan uap air dari udara sehingga bahan menjadi lembab atau kadar air bahan menjadi tinggi.

Uji beda Duncan terhadap perlakuan diperoleh hasil bahwa perlakuan A1T2 berbeda nyata $(p<0,05)$ terhadap A1T0, A0T0, A1T1, A0T1 dan A0T2. Perlakuan A1T0 tidak berbeda nyata dengan A0T0, tetapi berbeda nyata dengan A1T1, A0T1, A0T2 dan A1T2. Perlakuan A1T1 tidak berbeda nyata dengan A0T1 dan A0T2, tertapi berbeda nyata dengan A1T0, A0T0 dan A1T2. Hal ini menunjukkan bahwa penurunan mutu organoleptik khususnya tekstur ampas kelapa terjadi seiring 
meningkat dan menurunnya kandungan kadar air pada ampas kelapa. Tekstur ampas kelapa yang tidak ditambah ekstrak daun kersen memiliki tekstur yang remah dan kasar pada perlakuan T2. Halus dan kasarnya tekstur ampas kelapa dipengaruhi oleh kandungan dari bahan seperti kadar air dan kadar lemak. Rendahnya kandungan lemak pada ampas kelapa akan membuat tekstur ampas kelapa menjadi lebih kering. Hal ini sesuai dengan pendapat Ninsix (2012) yang menyatakan bahwa tekstur suatu bahan dapat dipengaruhi dari kandungan yang ada pada bahan tersebut yaitu lemak, serat dan protein. Menurut pendapat Kurniawan et al. (2016) yang menyatakan bahwa ampas kelapa yang memiliki kadar air yang tinggi akan menyebabkan pelebaran pori-pori sehingga tekstur menjadi lembut.

Nilai rataan lemak kasar pada perlakuan T0 dan T1 yaitu $8,53 \%$ dan $12,98 \%$. Perbedaan tekstur ampas kelapa yang diberi penambahan ekstrak daun kersen dan tidak diberi penambahan ekstrak daun kersen bisa disebabkan oleh kerusakan lemak karena reaksi oksidasi. Ampas kelapa yang tidak diberi ekstrak daun kersen akan mengalami reaksi oksidasi sehingga kandungan lemak kasar rendah sedangkan ampas kelapa yang diberi ekstrak daun kersen proses oksidasinya dapat dicegah oleh adanya flavonoid yang berguna sebagai antioksidan. Daun kersen mengandung flavonoid, tanin dan saponin, kandungan tersebut memiliki potensi antioksidan sehingga reaksi oksidasi pada ampas kelapa yang diberi ekstrak daun kersen dapat diturunkan. Hal ini sesuai dengan pendapat Kuntorini et al. (2013) yang menyatakan bahwa dalam kandungan daun kersen terdapat flavonoid, flavonoid merupakan suatu antioksidan alam yang mempunyai aktivitas biologis yang digunakan sebagai antioksidan yang mampu menghambat berbagai reaksi oksidasi.

\section{Warna Ampas Kelapa}

Berdasarkan hasil penelitian menunjukkan bahwa interaksi antara perlakuan penambahan ekstrak daun kersen (A) dan lama penyimpanan ( $\mathrm{T}$ ) berpengaruh sangat nyata $(\mathrm{P}<0,05)$ terhadap warna ampas kelapa.

Tabel 3. Rata-rata skor nilai warna pada ampas kelapa

\begin{tabular}{ccccc}
\hline \multirow{2}{*}{ Pemberian } & \multicolumn{3}{c}{ Lama penyimpanan } & \multirow{2}{*}{ Rata-rata } \\
\cline { 2 - 4 } Ekstrak & Minggu 0 & Minggu 2 & Minggu 4 & \\
\hline Tanpa Ekstrak (A0) & $3,09^{\mathrm{b}}$ & $2,64^{\mathrm{c}}$ & $2,40^{\mathrm{d}}$ & 2,71 \\
Dengan Ekstrak (A1) & $3,25^{\mathrm{a}}$ & $2,72^{\mathrm{c}}$ & $2,81^{\mathrm{c}}$ & 2,93 \\
\hline Rata-rata & 3,17 & 2,68 & 2,61 & \\
\hline
\end{tabular}

Superskrip yang berbeda pada baris dan kolom yang sama menunjukkan perbedaan yang sangat nyata $(p<0,05)$

Nilai rata-rata organoleptik terhadap warna berkisar antara 2,40 - 3,25. Skor tertinggi diperoleh pada perlakuan A1T0, ini terjadi karena warna yang dihasilkan pada perlakuan A1T0 masih seperti putih merata. Perlakuan A0T2 memiliki skor terendah karena warna ampas kelapa menjadi coklat kehitaman. Perubahan warna pada suatu bahan pakan dapat dipengaruhi oleh penyimpanan dan adanya mikroorganisme dari bahan pakan tersebut.
Uji beda Duncan terhadap perlakuan diperoleh hasil bahwa perlakuan A1T2 berbeda nyata $(\mathrm{p}<0,05)$ terhadap A1T0, A0T0, A1T1, A0T1 dan A0T2. Perlakuan A1T0 tidak berbeda nyata dengan A0T0, tetapi berbeda nyata dengan A1T1, A0T1, A0T2 dan A1T2. Perlakuan A1T1 tidak berbeda nyata dengan A0T1 dan A0T2, tertapi berbeda nyata dengan A1T0, A0T0 dan A1T2. Hal ini menunjukkan bahwa warna ampas kelapa yang tidak ditambah ekstrak daun kersen memiliki warna yang 
kuning kecoklatan. Selama penyimpanan pada saat kelembaban rendah maka cairan permukaan bahan akan banyak menguap sehingga pertumbuhan mikroorganisme terhambat dehidrasi, dan sebaliknya saat kelembaban relatif tinggi maka bahan pakan akan menyerap uap air sehingga mikroorganisme akan mulai tumbuh dan permukaan bahan menjadi gelap. Pemberian ekstrak daun kersen pada ampas kelapa akan menghambat tumbuhnya mikroorganisme karena daun kersen mempunyai kandungan flavonoid, tanin dan saponin yang memiliki sifat sebagai antimikroba. Hal ini sesuai dengan pendapat Mahardika et al. (2014) yang menyatakan bahwa ekstrak daun kersen mengandung senyawa aktif yaitu flavonoid sebagai antimikroba, senyawa aktif dalam daun kersen akan menghambat sintesis dinding sel, menggangu dan merusak dinding sel dan menghambat sintesis protein.

Warna bahan pakan yang berubah menjadi kehitam-hitaman menunjukkan bahwa bahan pakan tersebut telah ditumbuhi jamur. Hal ini sesuai dengan pendapat Ahmad (2009) yang menyatakan bahwa perubahan warna pada bahan pakan menjadi kehijauan dan kehitaman menandakan bahwa bahan pakan tersebut terserang jamur.

\section{Aroma Ampas Kelapa}

Berdasarkan hasil penelitian menunjukkan bahwa interaksi antara perlakuan penambahan ekstrak daun kersen (A) dan lama penyimpanan ( $\mathrm{T}$ ) berpengaruh sangat nyata $(\mathrm{P}<0,05)$ terhadap aroma ampas kelapa.

Tabel 4. Rata-rata skor nilai aroma pada ampas kelapa

\begin{tabular}{ccccc}
\hline \multirow{2}{*}{$\begin{array}{c}\text { Pemberian } \\
\text { Ekstrak }\end{array}$} & Minggu 0 & Minggu 2 & Minggu 4 & \multirow{2}{*}{ Rata-rata } \\
\cline { 2 - 4 } & T0 & T1 & T2 & \\
\hline Tanpa Ekstrak (A0) & $3,56^{\mathrm{a}}$ & $2,48^{\text {cd }}$ & $2,27^{\mathrm{d}}$ & 2,77 \\
Dengan Ekstrak (A1) & $3,40^{\mathrm{a}}$ & $2,88^{\mathrm{bc}}$ & $2,63^{\mathrm{cd}}$ & 2,97 \\
\hline Rata-rata & 3,48 & 2,68 & 2,45 & \\
\hline
\end{tabular}

Superskrip yang berbeda pada baris dan kolom yang sama menunjukkan perbedaan yang sangat nyata $(\mathrm{p}<0,05)$

Nilai rata-rata organoleptik terhadap aroma berkisar antara 2,45 - 3,48. Perlakuan A0T0 dan A1T0 memiliki skor yang hampir sama, hal ini terjadi akibat aroma yang dihasilkan pada perlakuan A0T0 dan A1T0 belum ada pengaruh penyimpanan pada minggu awal sehingga aromanya masih aroma asli khas ampas kelapa. Perlakuan A0T2 memiliki skor terendah karena aroma ampas kelapa menjadi tengik. Proses ketengikan dapat dipengaruhi oleh adanya prooksidan dan antioksidan. Prooksidan akan mempercepat terjadinya oksidasi sedangkan antioksidan akan menghambat proses oksidasi. Adanya antioksidan dalam lemak akan mengurangi kecepatan proses oksidasi, sehingga semakin banyak antioksidan yang diberikan maka semakin mempengaruhi terjadinya proses oksidasi. Hal ini sesuai dengan pendapat Ninsix (2012) yang menyatakan bahwa ketengikan dapat diakibatkan adanya kerusakan oksidatif dari lemak.

Uji beda Duncan terhadap perlakuan diperoleh hasil bahwa perlakuan A1T2 berbeda nyata $(p<0,05)$ terhadap A0T1, A1T0 dan A1T1, tetapi tidak berbeda nyata dengan A0T2 dan A0T1. Perlakuan A0T0 tidak berbeda nyata dengan A1T0, tetapi berbeda nyata dengan A1T1, A0T1, A0T2 dan A1T2. Perlakuan A1T1 tidak berbeda nyata dengan A0T1 dan A0T2, tertapi berbeda nyata dengan A0T0, A1T0 dan A1T2. Hal ini menunjukkan bahwa aroma ampas kelapa yang tidak diberi ekstrak daun kersen beraroma tengik, hal ini diakibatkan karena pada saat penyimpanan akan terjadi kerusakan fisik, kimia dan mikrobiologis, sehingga mengakibatkan aroma ampas kelapa menjadi tengik. Nilai rata-rata 
kandungan lemak kasar pada perlakuan A0 dan A1 yaitu sebesar 8,53 dan 12,98. Kandungan lemak kasar pada perlakuan A0 lebih rendah karena lemak yang terdapat pada ampas kelapa telah mengalami proses oksidasi sedangkan pada perlakuan T1 lemak pada ampas kelapa proses oksidasinya dihambat oleh zat antioksidan yang terdapat pada ekstrak daun kersen.

Beberapa upaya dilakukan untuk mengurangi kerusakan pada bahan pakan selain mengatur suhu dan kelembaban adalah dengan menambahkan zat aditif seperti bahan antioksidan dan anti jamur. Selama penyimpanan juga akan terjadi kerusakan lemak, kerusakan minyak selama proses penyimpanan akan mengakibatkan timbulnya ketengikan dan meningkatkan serangan mikroorganisme, hal itu karena adanya keterkaitan antara tekanan uap, kelembababan dan kadar air. Menurut pendapat Solihin (2015) aroma yang berubah menjadi aroma yang tidak diinginkan terjadi akibat mikroorganisme kerena mikroorganisme tersebut menghasilkan bau yang tidak sedap (tengik), mikroorganisme yang berperan yaitu bakteri, jamur dan mikroflora.

Ekstrak daun kersen yang ditambahkan pada ampas kelapa diduga mampu mengurangi jumlah bakteri pada ampas kelapa karena dalam kandungan daun kersen terdapat flavonoid, saponin dan tanin yang memiliki beberapa fungsi salah satunya sebagai antibakteri. Hal ini sesuai dengan pendapat Khasanah et al. (2014) yang menyatakan bahwa zat-zat aktif yang yang terkandung pada daun kersen seperti tanin, flavonoid dan saponin memiliki fungsi sebagai antibakteri, semakin tinggi konsentrasi ekstrak yang ditambahkan maka akan semakin rendah jumlah bakteri yang tumbuh.

\section{Jamur pada Ampas Kelapa}

Berdasarkan hasil penelitian menunjukkan bahwa interaksi antara perlakuan penambahan ekstrak daun kersen (A) dan lama penyimpanan ( $\mathrm{T}$ ) berpengaruh sangat nyata $(\mathrm{P}<0,05)$ terhadap ada tidaknya jamur pada ampas kelapa.

Tabel 5. Rata-rata skor nilai jamur pada ampas kelapa

\begin{tabular}{ccccc}
\hline \multirow{2}{*}{$\begin{array}{c}\text { Pemberian } \\
\text { Ekstrak }\end{array}$} & \multicolumn{3}{c}{ Lama penyimpanan } & \multirow{2}{*}{ Rata-rata } \\
\cline { 2 - 4 } & Minggu 0 & Minggu & Minggu 4 & \\
\hline Tanpa Ekstrak (A0) & $3,48^{\mathrm{a}}$ & $2,89^{\mathrm{b}}$ & $2,24^{\mathrm{d}}$ & 2,87 \\
Dengan Ekstrak (A1) & $3,47^{\mathrm{a}}$ & $3,03^{\mathrm{b}}$ & $2,64^{\mathrm{c}}$ & 3,05 \\
\hline Rata-rata & 3,48 & 2,96 & 2,44 &
\end{tabular}

Superskrip yang berbeda pada baris dan kolom yang sama menunjukkan perbedaan yang sangat nyata $(p<0,05)$

Nilai rata-rata organoleptik terhadap ada tidaknya jamur berkisar antara 2,44 3,48. Skor tertinggi diperoleh pada perlakuan A0T0, ini terjadi karena jamur masih belum muncul pada ampas kelapa. Perlakuan A0T2 memiliki skor terendah karena jamur mulai bermunculan pada ampas kelapa.

Uji beda Duncan terhadap perlakuan diperoleh hasil bahwa perlakuan A1T2 berbeda nyata $(\mathrm{p}<0,05)$ terhadap A0T2, A0T0, A1T0, A1T1 dan A0T1. Perlakuan A0T2 berbeda nyata $(\mathrm{p}<0,05)$ terhadap A0T0, A1T0, A1T1, A0T1 dan A1T2.
Perlakuan A0T0 tidak berbeda nyata dengan A1T0, tetapi berbeda nyata dengan A1T1, A0T1, A1T2 dan A0T2. Perlakuan A1T1 tidak berbeda nyata dengan A0T1, tertapi berbeda nyata dengan A1T2, A0T2, A0T0 dan A1T0. Hal ini menunjukkan bahwa proses penyimpanan sangat mempengaruhi kualitas ampas kelapa, salah satu indikator penurunan kualitas yaitu adanya kontaminasi mikroorganisme yang ditandai dengan munculnya jamur. Hal ini sesuai dengan pendapat Solihin et al. (2015) yang menyatakan bahwa perubahan kualitas pada 
pakan selama penyimpanan terjadi akibat aktivitas mikrobial seperti jamur. Penurunan kualitas ampas kelapa pada minggu kedua juga dapat disebabkan penggunaan kemasan yang salah.

Kain blacu yang memiliki sifat menyerap air dan memiliki rongga udara yang luas sehingga terjadi pertukaran udara yang bebas, sehingga dapat diduga kandungan air yang terdapat pada ampas kelapa terserap oleh kain blacu sehingga menyebabkan kain blacu basah dan menimbulkan tumbuhnya jamur. Hal ini sesuai dengan pendapat Nurhasyibi dan Sudrajat (2016) yang menyatakan bahwa kain blacu menimbulkan kelembaban yang tinggi dan menyebabkan peningkatan kadar air.

Menurut Hermawan et al. (2015) adanya jamur pada bahan pakan dimungkinkan karena terjadinya peningkatan kadar air pada waktu penyimpanan dan adanya aktivitas mikroba. Penambahan ekstrak daun kersen pada ampas kelapa diduga mampu mengurangi aktivitas mikroba sehingga jumlah jamur pada ampas kelapa mampu berkurang, karena dalam kandungan daun kersen terdapat flavonoid, saponin dan tanin. Saponin dalam daun kersen memiliki peran sebagai antimikroba, karena saponin mampu menggangu permeabilitas membran sel mikroba. Hal ini sesuai dengan pendapat Kurniawan et al. (2014) yang menyatakan bahwa saponin merupakan metabolit sekunder yang bersifat antimikroba, saponin akan menggangu tegangan permukaan dinding sel pada mikroba.

\section{KESIMPULAN}

Lama penyimpanan mampu menurunkan kualitas organoleptik dan pemberian ekstrak daun kersen pada ampas kelapa mampu menekan terjadinya penurunan kualitas organoleptik dari ampas kelapa meliputi tekstur, warna, aroma dan ada tidaknya jamur.

\section{DAFTAR PUSTAKA}

Afrianto, E. dan E. Liviawaty. 2009. Pakan Ikan. Kanisius. Yogyakarta.

Ahmad, 2009. Cemaran kapang pada pakan dan pengendaliannya. J Litbang Pertanian. 28: 15-22.

Ahmad, R.Z. 2017. Cemaran kapang pada pakan dan pengendaliannya. J. Penelitian dan Pengembangan Pertanian. 28(1) : 15-22.

Alamsyah, S dan M. Y. Karim. 2012. Uji Organolepti, fisik dan kimiawi pakanbuatan untuk ikan bandeng yang disubstitusi dengan tepung cacing tanah (Lumbricus sp). J. Akuakultur Indonesia 11(2) : 124-131.

Asrawaty. 2015. Karakteristik tepung kelapa limbah usaha pemarutan dan pemerasan santan di pasar inpres manonda. Jurnal Kiat Universitas Alkhairaat. 7(1) : 71-77.

Cahya, F dan W. H. Susanto. 2014. Pengaruh pohon pasca sadap dan kematangan buah kelapa terhadap sifat fisik, kimia, organoleptik pasta santan. Jurnal Pangan dan Agroindustri. 2(4) : 249258.

Dwi, A P dan H. Sasongko. 2014. Aktivitas antibakteri ekstrak etanol $70 \%$ daun kersen (Muntingia Calabura L.) terhadap bakteri bacillus subtilis dan Shigella dysenteriae Sebagai Materi Pembelajaran Biologi SMA Kelas X untuk mencapai $\mathrm{Kd} 3.4$ pada Kurikulum 2013. Jupemasi pbio. 1 (1) : 98-102.

Elyana, P. 2011. Pengaruh penambahan ampas kelapa hasil fermentasi Aspergillus oryzae dalam pakan komersial terhadap pertumbuhan ikan nila (Oreochromis niloticus Linn.). Fakultas Matematika dan Ilmu 
Pengetahuan Alam Universitas

Sebelas Maret, Surakarta. (Skripsi Sarjana Sains).

Handarsari, E. 2010. Eksperimen pembuatan sugar pastry dengan substitusi tepung ampas tahu. Jurnal Pangan dan Gizi. $1(1): 35-42$.

Harris, R. S. dan E. Karnas. 1989. Evaluasi Nilai Gizi pada Pengolahan Bahan Pangan. ITB Press, Bandung.

Herawati, H. 2008. Penentuan umur simpan pada produk pangan. Jurnal Litbang Pertanian. 27(4) : 124-130.

Hermawan, S. R dan Muhtarudin. 2015. Kualitas fisik, kadar air dan sebaran jamur pada wafer limbah pertanian dengan lama simpan yang berbeda. Jurnal Ilmiah Peternakan Terpadu. 3(2) : 55-60.

Imdad, H. P. dan A.A. Nawangsih. 1999. Menyimpan Bahan Pangan. Penebar Swadaya, Jakarta.

Irena, A. 2010. Isolasi dan optimasi protease bakteritermofilik dari sumber air panas takuban perahu bandung. Fakultas Matematika dan Pengetahuan Alam. Institut Pertanian Bogor, Bogor. (Skripsi Sarjana Sains).

Ismanto, A., S. Sunarti, L.D. Mahfudz. 2012. Pengaruh pemberian pakan bebas pilih terhadap kecernaan protein burung puyuh. Animal Agriculture Journal. $1(2): 238-245$.

Izzah, S.U. 2011. Pengaruh Diameter Pelet dan Lama Penyimpanan Terhadap Kualitas Fisik Pelet Daun Legum Indigofera sp. Fakultas Peternakan. Institut Pertanian Bogor, Bogor. (Skripsi Sarjan Peternakan).

Karlina, C. Y., M. Ibrahim dan G. Trimulyono. 2013. Aktivitas antibakteri ekstrak herba krokot
(Portulaca oieracea L.) terhadap staphylococcus aureus dan Eschericia coli. Electronic Journal UNESA Lentera Bio. 2(1): 87-93.

Khasanah, I., Sarwiyono dan P. Surjowardojo. 2014. Ekstrak etanol daun kersen (Muntingia calabura L.) sebagai antibakteri terhadap Streptococcus agalactiae penyebab mastitis subklinis pada sapi perah. J. Ternak Tropika. 15(2): 7-14.

Krisnan, R. 2008. Perubahan karakteristik fisik konsentrat domba selama penyimpanan. Seminar Nasional Teknologi Peternakan dan Veteriner. Bogor. Hal : 491-497.

Kubra, N. 2018. Kualitas wafer dari bahan baku lokal sebagai pakan ternak ruminansia. J. Ilmiah Peternakan 6(1) :51-57.

Kuntorini, E. M., S. Fitriana dan M. D. Astuti. 2013. Struktur Anatomi Antioksidan Ekstrak Metanol Daun Kersen (Muntingia calabura). Prosiding Semirata Fakultas MIPA, Universitas Lampung, Bandar Lampung.

Kurniawan, H., R. Utomo dan L. M. Yusiati. 2016. Kualitas nutrisi ampas kelapa (cocos nucifera L.) fermentasi menggunakan Aspergillus niger. Buletin Peternakan. 40 (1): 26-33

Kushartono, B. 2000. Penentuan Kualitas Bahan Baku Pakan dengan Cara Organoleptik. Balai Penelitian Bogor, Bogor

Mahardika, H.A., Sarwiyono dan P. Surjowardojo. 2014. Ekstrak metanol daun kersen (Muntingia calabura L.) sebagai antimikroba alami terhadap bakteri Staphylococcus aureus penyebab mastitis subklinis pada sapi 
perah. Jurnal Ternak Tropika. 15(2): $15-22$.

Miftahudin, Liman dan F. Fathul. 2015. Pengaruh masa simpan terhadap kualitas fisik dan kadar air pada wafer limbah pertanian berbasis wortel. Jurnal Ilmiah Peternakan Terpadu. 3(3): 121-126.

Mirzoeva, O. K., R. N. Grishanin and P. C. Calder. 1997. Antimicrobial Action of Propolis and Some of Its Components: the Effect on Growth, Membrane Potential and Motility of Bacteria. Microbial. Res.152 (5): 239-46.

Miskiyah., I. Mulyawati dan W. Haliza. 2006. Pemanfaataan ampas kelapa limbah pengolahan minyak kelapa murni menjadi pakan . Seminar Nasional Teknologi Peternakan dan Veteriner. Bogor. Hal : 880- 884.

Ninsix, R. 2012. Pengaruh ekstraksi lemak terhadap rendemen dan karakteristik tepung ampas kelapa yang dihasilkan. J. Teknologi Pertanian. 1(1) : 1-77.

Nurhasyibi dan D. J. Sudrajat. Penentuan daya simpan benih suren (Toona sureni Merr.) di alam melalui penyimpanan soil seed bank. J. Pembenihan tanaman hutan. 4(1) : 33-41.

Pasaribu, T., T. Purwadaria., A.P. Sinurat., J. Rosida dan D.O.D Saputra. 2001. Evaluasi nilai gizi lumpur sawit hasil fermentasi dengan Aspergillus niger pada berbagai perlakuan penyimpanan. J. Ilmu Ternak dan Veteriner 6(4) : 233-238.

Purbajanti, E. D. 2013. Rumput dan Legum Sebagai Hijauan Makanan Ternak. Graha Ilmu, Yogyakarta.

Puspitasari, A. D. dan L. S. Prayogo. 2016. Perbandingan metode ekstraksi maserasi dan sokletasi terhadap kadar flavonoid total ekstrak etanol daun kersen (Muntingia calabura). Fakultas Farmasi, Universitas Wahid Hasyim, Semarang.

Putri, M. F. 2010. Tepung ampas kelapa pada umur panen 11-12 bulan sebagai bahan pangan sumber kesehatan. Jurusan Teknologi Jasa dan Produksi, Universitas Negeri Semarang. Semarang. Jurnal Kompetisi Teknik

Retnani, Y., D. Wigati dan A.D. Hasjmy. 2009. Pengaruh jenis kemasan dan lama penyimpanan terhadap serangan serangga dan sifat fisik ransum Broiler starter berbentuk crumble. J. Ilmu-ilmu Peternakan. Agustus 12(3) 137:145.

Solihin., Muhtarudin dan R. Sutrisna. 2015. Pengaruh lama penyimpanan terhadap kadar air kualitas fisik dan sebaran jamur wafer limbah sayur dan umbiumbian. J. Ilmu Peternakan Terpadu. $3(2): 48-54$.

Syam, P. L. 2017. Perbandingan metode ekstrasi terhadap kadar flavonoid total ekstrak metanol daun kresen (Muntingia calabura L.). Fakultas Farmasi Universitas Wahid Hasyim, Semarang. (Skripsi Sarjana Farmasi)

Syarief dan Halid. 1994. Teknologi Penyimpanan Pangan. Penerbit Arcan. Pusat Antar Universitas Pangan dan Gizi. Institut Pertanian Bogor, Bogor.

Triyanto, E., B.W.H.E. Prasetiyono dan S. Mukodiningsih. 2013. Pengaruh bahan pengemasan dan lama simpan terhadap kualitas fisik dan kimia wafer pakan komplit berbasis limbah agroindustri. Animal Agriculture Journal. 2(1) : 400409.

Wigati, D. 2009. Pengaruh jenis kemasan dan lama penyimpanan terhadap seranganserangan dan sifat fisik ransum broiler starter berbentuk crumble. Fakultas 
Peternakan Institut Pertanian Bogor, Yuswantina, R. 2009. Uji aktivitas Bogor. (Skripsi Sarjana Peternakan)

Yulvianti, M ., M. Ernayati., Tarsono dan M. Alfian R. 2015. Pemanfaatan ampas kelapa sebagai bahan baku tepung kelapa tinggi serat dengan metode Freeze Drying. Jurnal Integrasi Proses. $5(2)$ : 101-107.

penangkap radikal dari ekstrak petroleum eter, etil asetat dan etanol rhizoma binahong (Anredera cordifolia (Tenore) Steen) dengan metode DPPH (2,2-difenil-1-pikrihidrazil). Fakultas Farmasi Universitas Muhammadiyah, Surakarta. (Skripsi Sarjana Farmasi) 